\title{
Memory deficit associated with increased brain proinflammatory cytokine levels and neurodegeneration in acute ischemic stroke
}

Déficit de memória associado ao aumento dos níveis cerebrais de citocinas pró-inflamatórias e neurodegeneração na isquemia cerebral aguda

Bruno Silva ${ }^{1}$, Larissa Sousa ${ }^{1}$, Aline Miranda², Anilton Vasconcelos ${ }^{1}$, Helton Reis ${ }^{3}$, Luciola Barcelos ${ }^{4}$, Rosa

Arantes ${ }^{1}$, Antonio Teixeira², Milene Alvarenga Rachid ${ }^{1}$

\begin{abstract}
The present study aimed to investigate behavioral changes and neuroinflammatory process following left unilateral common carotid artery occlusion ( $U C C A_{0}$ ), a model of cerebral ischemia. Post-ischemic behavioral changes following 15 min UCCA were recorded 24 hours after reperfusion. The novel object recognition task was used to assess learning and memory. After behavioral test, brains from sham and ischemic mice were removed and processed to evaluate central nervous system pathology by TTC and H\&E techniques as well as inflammatory mediators by ELISA. UCCA, promoted long-term memory impairment after reperfusion. Infarct areas were observed in the cerebrum by TTC stain. Moreover, the histopathological analysis revealed cerebral necrotic cavities surrounded by ischemic neurons and hippocampal neurodegeneration. In parallel with memory dysfunction, brain levels of TNF-a, IL-1b and CXCL1 were increased post ischemia compared with sham-operated group. These findings suggest an involvement of central nervous system inflammatory mediators and brain damage in cognitive impairment following unilateral acute ischemia.
\end{abstract}

Keywords: brain, ischemia, memory, inflammation, cytokines.

\section{RESUMO}

O presente estudo teve como objetivo investigar alterações comportamentais e processos inflamatórios na isquemia cerebral induzida pela oclusão unilateral da carótida comum esquerda (UCCA $)$ em camundongos. As alterações comportamentais foram avaliadas após 15 minutos de isquemia e 24 horas de reperfusão. 0 teste de reconhecimento de objetos foi utilizado para avaliação da memória e do aprendizado. Em seguida, os animais foram mortos e os encéfalos foram coletados e processados para avaliação das alterações patológicas pelas técnicas de TTC e H\&E, assim como da dosagem de mediadores inflamatórios por ELISA. A UCCA, promoveu alterações de memória após a reperfusão. Foram visualizadas áreas de infarto cerebral pela coloração de TTC e cavidades necróticas circundadas por neurônios isquêmicos no cérebro e neurodegeneração hipocampal. A UCCA causou aumento dos níveis encefálicos de TNF-a, IL-1b e CXCL1. Estes achados demonstraram o envolvimento dos mediadores inflamatórios no sistema nervoso central e da neurodegeneração no déficit cognitivo após isquemia cerebral aguda.

Palavras-chave: encéfalo, isquemia, memória, inflamação, citocinas.

Stroke is one of the leading causes of death and disabilities worldwide. Among various subtypes, ischemic stroke due to occlusion of a cerebral blood vessel occurs most frequently ${ }^{1}$. Due to the advances in intravascular techniques and thrombolytic agents, transient focal cerebral ischemia has become one of the most common types of ischemic stroke ${ }^{2}$. Unilateral common carotid artery occlusion (UCCAo) in C57BL/6J mice has been employed as a model of unilateral severe human carotid artery stenosis, causing intense brain damage in vulnerable areas including hippocampus, striatum and cerebral

\footnotetext{
'Universidade Federal de Minas Gerais, Instituto de Ciências Biológicas, Departamento de Patologia Geral, Belo Horizonte MG, Brazil;

¿Universidade Federal de Minas Gerais, Faculdade de Medicina, Clínica Médica, Belo Horizonte MG, Brazil;

${ }^{3}$ Universidade Federal de Minas Gerais, Instituto de Ciências Biológicas, Departamento de Farmacologia, Belo Horizonte MG, Brazil;

${ }^{4}$ Universidade Federal de Minas Gerais, Instituto de Ciências Biológicas, Fisiologia e Biofísica, Belo Horizonte MG, Brazil.

Correspondence: Milene Rachid; Instituto de Ciências Biológicas, Departamento de Patologia Geral/UFMG; Av. ICB, 6627/ Bloco F3/ Sala 312; $31270-901$ Belo Horizonte MG, Brasil; E-mail: milenerachid@gmail.com

Conflict of interest: There is no conflict of interest to declare.

Support: This work was supported by CAPES, CNPq and Fapemig.

Received 31 October 2014; Received in final form 22 March 2015; Accepted 10 April 2015.
} 
cortex ${ }^{3,4}$. Interestingly, reperfusion may paradoxically exacerbate brain injury, by involvement of neutrophils, glial reaction, cytokine and chemokine production ${ }^{5,6,7}$. Cognitive deficits have often been reported following brain ischemia, being memory the most affected domain, followed by attention and executive function ${ }^{8,9}$. To the best of our knowledge, no previous study investigated the role of central nervous system (CNS) inflammation in the development of cognitive impairment in acute brain stroke following experimental unilateral common carotid artery occlusion. Thus, the aim of the current study was to investigate the association between memory deficits, neuropathology and CNS inflammatory cytokines in adult C57BL/ 6 mice submitted to UCCAo.

\section{METHOD}

\section{Animals}

The Animal Ethics Committee of Federal University of Minas Gerais (UFMG) approved all experiments (protocol 4412/2012). Eight-to-ten-week-old male C57BL/6J mice were obtained from the Centro de Bioterismo of the UFMG, in Brazil, and kept in the animal facilities of the Immunopharmacology Laboratory, in Department of Biochemistry and Immunology at Biological Science Institute, UFMG. Mice were maintained with filtered water and food in a controlled environment (stable temperature and humidity).

\section{Unilateral common carotid artery occlusion (UCCA,)}

Mice were anesthetized by intraperitoneal injection of ketamine hydrochloride $(150 \mathrm{mg} / \mathrm{kg})$ and xylazine (10 mg/kg). Transient cerebral ischemia was induced by occlusion of the left common carotid artery (UCCA O $_{0}$. Briefly, a midline cervical incision was made and the left common carotid artery was exposed and occluded using microaneurysm clamps. The clamps were removed after 15 minutes of occlusion. In the sham group, arteries were visualized, but not occluded ${ }^{10,11}$.

\section{Novel object recognition task}

The novel object recognition task is based on the innate tendency of rodents to differentially explore novel objects over familiar ones ${ }^{12}$. The object recognition task was performed to assess memory 24 hours after ischemia as previously described ${ }^{13}$. Briefly, animals had the opportunity to explore an open field for $5 \mathrm{~min}$ (habituation session). On the following day, a training session was conducted by placing individual mice for $5 \mathrm{~min}$ into the field in the center of the arena, in which two identical objects (object A1 and A2 were positioned in two adjacent corners at $10 \mathrm{~cm}$ from the walls). In the long-term memory (LTM) test (24 h after training), the mice explored the field for $5 \mathrm{~min}$ in the presence of a familiar (A) and a different novel (B) object. Objects (Lego toys) had only distinction in shape. The exploratory preference was defined as the percentage of total time (seconds) that the animal spent investigating the novel object and calculated for each animal by the ratio TB $/(\mathrm{TA}+\mathrm{TB})^{*} 100$ $[\mathrm{TA}=$ time spent exploring the familiar object $\mathrm{A} ; \mathrm{TB}=$ time spent exploring the novel object B). The distance traveled in the apparatus arena was also recorded as a locomotor activity parameter. The Anymaze software (Stoelting Co., Wood Dale, IL, USA) was employed for behavioral analysis. All tests were performed by the same investigator who was blinded to the animal status (sham operated or I/R). A total of ten animals per group were used.

\section{Assessment of cerebral infarction}

At $24 \mathrm{~h}$ after $\mathrm{UCCA}_{0}$, mice were deeply anesthetized and brains were removed. The brain was carefully removed and placed in a mouse brain matrix slicer (Insight Ltda., Ribeirão Preto, SP, Brazil), and the entire brain was coronally sectioned at $2 \mathrm{~mm}$ intervals. Sections were incubated for 30 minutes in $2 \%$ TTC in saline at $37^{\circ} \mathrm{C}$ and fixed in formalin for 24 hours. Infarcted (unstained) and viable tissue (stained) areas from brain sections were imaged.

\section{Histopathological examination}

Brains from sham and $\mathrm{UCCA}_{\mathrm{O}}$ mice were preserved in $10 \%$ buffered formalin. Sections of $5 \mu \mathrm{m}$ thickness were cut at intervals of $10 \mu \mathrm{m}$ and mounted for hematoxylin and eosin staining.

\section{ELISA of proteins in cerebral tissue}

Brain tissue extracts were obtained from sham-operated and $\mathrm{UCCA}_{\mathrm{O}}$ mice at 24 hours after the ischemia and stored at $-20^{\circ} \mathrm{C}$. Thereafter, the brain tissue was homogenized in an extraction solution (100 mg of tissue per $1 \mathrm{~mL}$ of extraction solution) containing $0.4 \mathrm{~mol} / \mathrm{L} \mathrm{NaCl}, 0.05 \%$ Tween $^{\text {mi }} 20,0.5 \%$ BSA, $0.1 \mathrm{mmol} / \mathrm{L}$ phenylmethyl sulfonil fluoride, $0.1 \mathrm{mmol} / \mathrm{L}$ benzethonium chloride, $10 \mathrm{mmol} / \mathrm{L}$ EDTA, and $20 \mathrm{KI}$ aprotinin, using Ultra-Turrax (Fisher Scientific, Pittsburgh, PA, USA). The brain homogenate was centrifuged at $3000 \times g$ for 10 min at $4^{\circ} \mathrm{C}$, and the supernatant was collected and stored at $-20^{\circ} \mathrm{C}$. Concentrations of the cytokines TNF-a and IL-1b and of the chemokine CXCL1 were determined using ELISA. The brain tissue supernatants were assayed in an ELISA setup using commercially available antibodies, according to the manufacturer's procedures (R\&D Systems, Minneapolis, MN, USA).

\section{Statistical analysis}

Data are shown as mean \pm SEM. The $t$ student was used for comparisons between two groups. Statistical significance was set at $\mathrm{p}<0.05$.

\section{RESULTS}

The effect of unilateral common carotid artery occlusion and reperfusion in cognition was analyzed using novel object recognition task. $\mathrm{UCCA}_{\mathrm{O}}$ mice presented an impairment of 
long-term memory 24 hours after ischemia compared to controls, indicated by a significant reduction in the percentage of time exploring the novel object (Figure 1A; $<$ 0.05). There was no significant difference observed in the distance travelled between $\mathrm{UCCA}_{\mathrm{O}}$ and sham groups, indicating no difference in motor activity (Figure 1B) ( $\mathrm{n}=10$ per group).

Representative coronal brain sections from UCCAo group are shown in Figure 2. TTC staining shows deep red staining of normal brain tissue and white nonstaining of the infarct areas in the cerebrum (asterisks). No morphological changes were observed in brain tissue from sham-operated mice (Figure 3A: hippocampus and D: cerebral cortex). H\&E sections from UCCAo mice showed several shrunken neurons with triangulated pyknotic nuclei in all hippocampal subfields (CA1-CA4) (Figure 3B) and hemorrhagic foci (Figure $3 \mathrm{C})$. Ischemic neurons were also observed in the cerebral cortex (Figure 3E). Infarcted areas characterized by formation of cavities surrounded by ischemic neurons were visualized in the cerebrum (Figure 3F).

The inflammatory mediators were measured in the brain from sham and UCCA ${ }_{0}$ animals. The concentrations of TNF-a

A

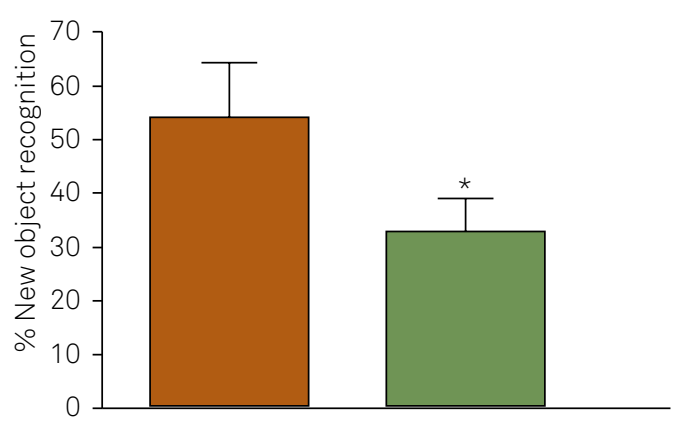

B

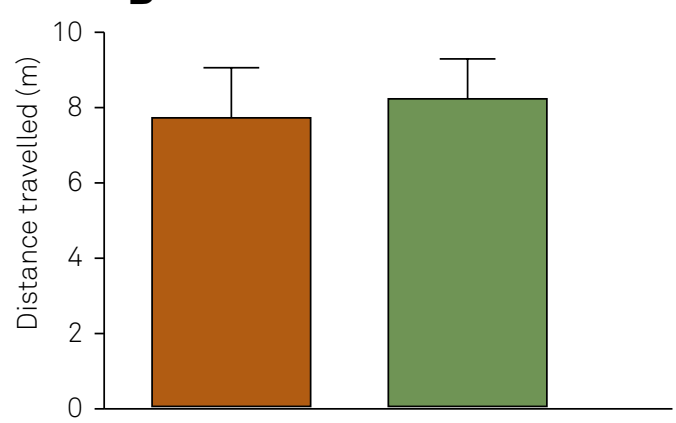

Figure 1. Novel object recognition memory impairment without locomotor changes following brain ischemia and reperfusion. C57BL/6 mice ( $n=10$ per group) were submitted to 15 minutes of ischemia and 24 hours of reperfusion (I/R group). Sham-operated animals were anesthetized and arteries were only exposed ( $n=10$ per group). All animals were submitted to object recognition task training and test session, respectively. (A) Long-term memory and (B) distance travelled were recorded 24 hours after ischemia. Results are expressed as mean \pm SEM and are representative of at least two independent experiments. Asterisk indicates statistical difference $\left({ }^{*} p<0.05\right)$. and IL-1b in the CNS of $\mathrm{UCCA}_{\mathrm{O}}$ mice were significantly increased in comparison with sham animals $(\mathrm{p}<0.05)$. Higher levels of CXCL1 were also detected in $\mathrm{UCCA}_{\mathrm{O}}$ animals compared with sham. $(\mathrm{p}<0.005)$ (Figure 4: $\mathrm{n}=6$ per group).

\section{DISCUSSION}

Cerebrovascular diseases can directly or indirectly damage brain structures associated with cognitive functions. There is evidence of cognitive decline in patients with large volume of brain ischemia or multiple cortical microinfarcts $^{14,15}$. Clinically asymptomatic vascular brain injury might also cause cognitive impairment ${ }^{8}$. In the current study, we demonstrated that object recognition memory impairment was associated with histopathological lesions in cerebrum and hippocampus of UCCA $\mathrm{U}_{\mathrm{O}}$ mice. Moreover, an increase in CNS inflammatory cytokines was also found following acute brain ischemia and reperfusion. In the evaluated period, $\mathrm{UCCA}_{\mathrm{O}}$ did not induced locomotor alterations, which supports this model as a valuable tool to study memory impairment following ischemia. Cerebral ischemia can cause severe neuronal injury and death, which can further lead to learning and memory impairment in patients ${ }^{9}$. Hippocampus plays a vital role in information processing, memory formation, and subsequent regulation of behavior ${ }^{16}$. In our study, cognitive deficit was accompanied by neuronal death in hippocampal $\mathrm{CA}$ region 24 hours after reperfusion. The acute brain ischemia induced in this work could be a suitable model to study cognitive changes and neurodegeneration characterized by large cortical infarcts and hippocampal neuronal loss.

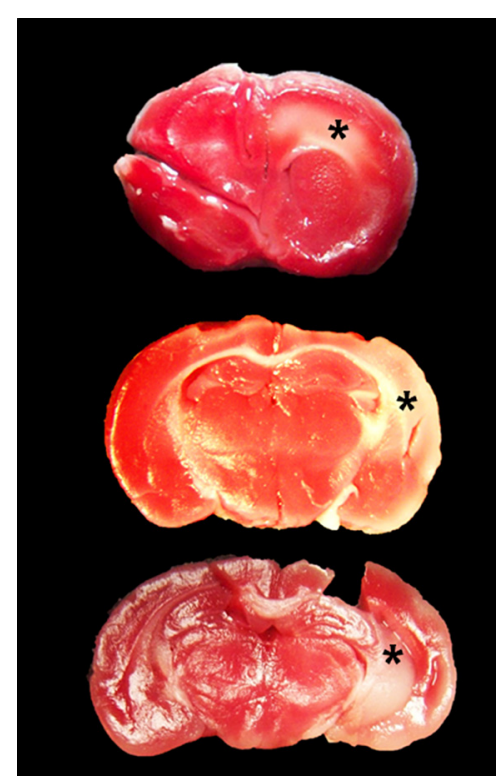

Figure 2. Representative TTC stained brain sections were shown where mice were subjected to 15 minutes of ischemia followed by $24 \mathrm{~h}$ reperfusion (I/R). White is infarct area and red is normal area. Infarcted areas were visualized in the cerebrum and hippocampus (asterisks). 

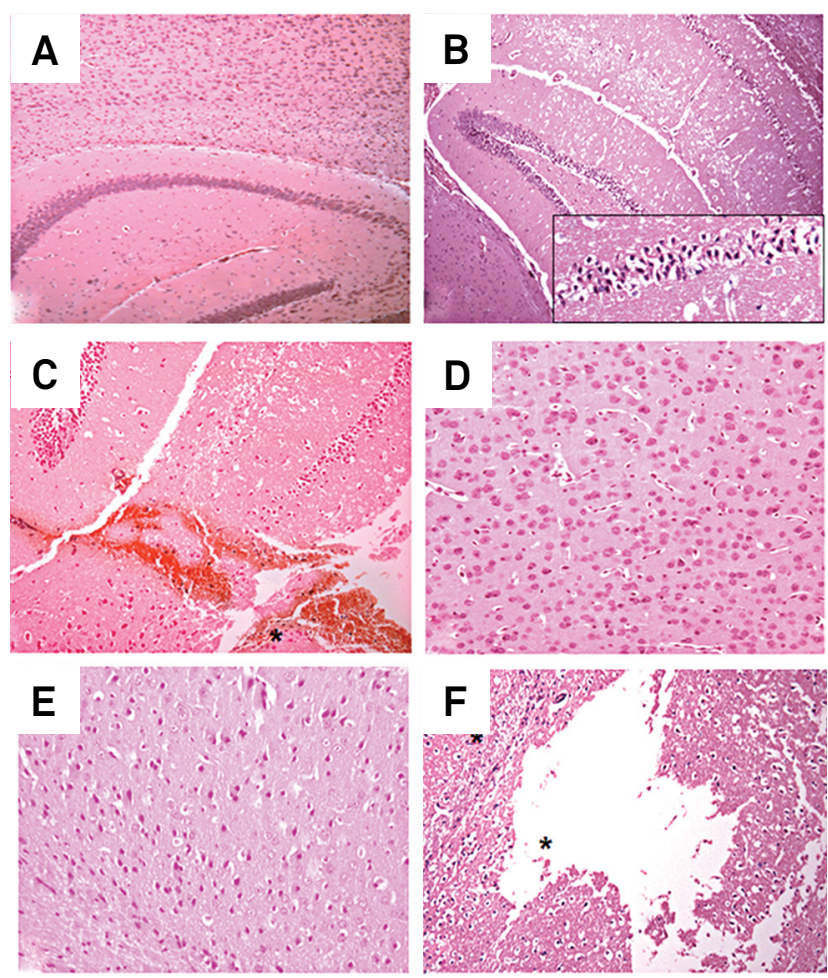

Figure 3. Histopathology analysis of brain sections of Sham $(A, D)$ and Ischemic/reperfusion mice (B-C, E-F). H\&E-stained sections. (A) Hippocampus and cerebral cortex (C) of Sham mouse showing normal tissue with intact neurons. Ischemic/ reperfusion mouse exhibiting hippocampus with numerous degenerated neurons in CA areas (insert) and dentate gyrus (B). Cerebral cortex showing cavity surrounded by ischemic neurons (asterisks) (D). Original magnification: A-B:x100. C-D:x200.

We also observed marked cytokine and chemokine up-regulation (IL-1ß, TNF- $\alpha$ and CXCL1) after stroke. Astroglial and microglial reaction to the ischemic brain induces the production of inflammatory cytokines and chemokines ${ }^{6,17}$. We measured the expression of the chemokine CXCL1, the rodent homolog of human IL-8, which is chemoattractant for neutrophils. Neutrophils are the first inflammatory cells in the ischemic tissue and during reperfusion contribute to expansion of brain injury by production of radical oxygen species, proteinases and cytokines ${ }^{7,10}$. We previously demonstrated that blockade of CXCR1/2 receptors by reparixin promoted neuroprotective effects by reducing the levels of neutrophil infiltration and tissue damage in the brain after cerebral occlusion and reperfusion in mice ${ }^{7}$. We also detected increased levels of pro-inflammatory cytokines TNF- $\alpha$ and IL- $1 \beta$, which can contribute to the expansion of brain damage and death of neurons ${ }^{18}$. Under physiological conditions, IL- $1 \beta$ and TNF- $\alpha$ play an important role in neurogenesis, synaptic plasticity, long-term potentiation (LTP) and memory formation and consolidation ${ }^{19,20}$. On the other hand, the over-expression of these cytokines in the CNS has been associated with behavioral and cognitive impairment in several

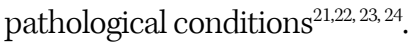

There are some limitations in the present study. The study is largely descriptive and does not show proof of causality.

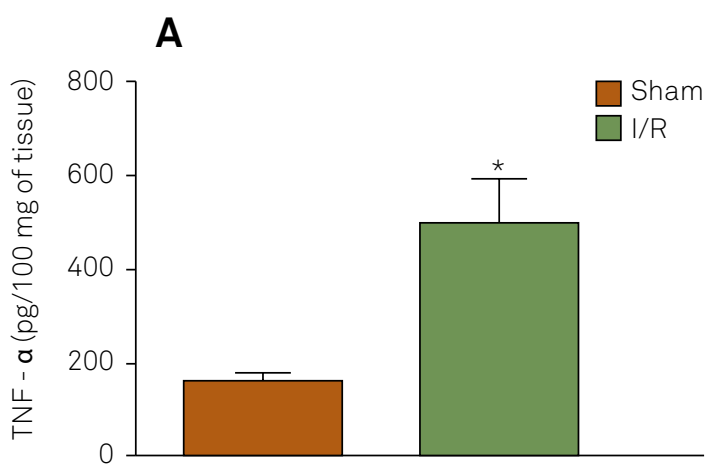

B

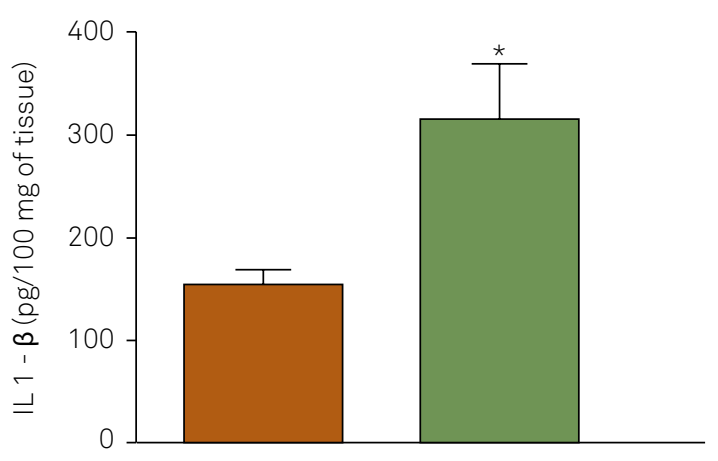

C

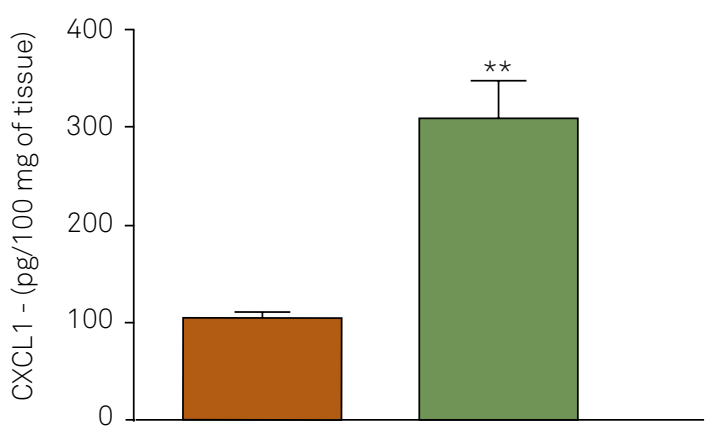

Figure 4. Brain ischemia and reperfusion induces an increase in tissue levels of TNF- $\alpha$, IL-1- $\beta$ and CXCL1. The figure shows the levels of TNF- $\alpha, I L-1-\beta$ and CXCL1 in brain tissues of mice submitted (IR) and not submitted (Sham) to brain ischemia and 24 hours of reperfusion and measured by ELISA. The results are expressed as mean \pm SEM ( $n=6$ per group). Asterisks indicate ${ }^{*} p<0.05$ and ${ }^{*} p<0.001$ compared to Sham group.

Several studies have examined the pathophysiological mechanisms underlying the ischemic process, with the objective of discovering potential targets in the treatment of stroke. Therefore, efforts need to be done not only to preserve the cerebral blood flow, but also to prevent the mechanisms that trigger brain damage after ischemia.

In conclusion, we found that memory deficits after acute brain ischemia are associated with increased levels of brain pro-inflammatory cytokines and neurodegeneration. These findings suggest a role for CNS inflammatory mediators and brain damage in cognitive impairment following ischemia. 


\section{References}

1. Rodgers H. Stroke. Handb Clin Neurol. 2013;110:427-33. http://dx.doi.org/10.1016/B978-0-444-52901-5.00036-8

2. Jin X, Liu J, Liu W. Early ischemic blood brain barrier damage: a potential indicator for hemorrhagic transformation following tissue plasminogen activator (tPA) thrombolysis? Curr Neurovasc Res. 2014;11(3):254-62. http://dx.doi.org/10.2174/1567202611666140530145643

3. Plaschke K, Staub J, Ernst E, Marti HH. VEGF overexpression improves mice cognitive abilities after unilateral common carotid artery occlusion. Exp Neurol. 2008;214(2):285-92. http://dx.doi.org/10.1016/j.expneurol.2008.08.014

4. Guo H, Itoh Y, Toriumi H, Yamada S, Tomita Y, Hoshino H et al. Capillary remodeling and collateral growth without angiogenesis after unilateral common carotid artery occlusion in mice. Microcirculation. 2011;18(3):221-7. http://dx.doi.org/10.1111/j.1549-8719.2011.00081.x

5. Amantea D, Nappi G, Bernardi G, Bagetta G, Corasaniti MT. Post-ischemic brain damage: pathophysiology and role of inflammatory mediators. FEBS J. 2009;276(1):13-26. http://dx.doi.org/10.1111/j.1742-4658.2008.06766.x

6. Jin R, Yang G, Li G. Inflammatory mechanisms in ischemic stroke: role of inflammatory cells.J Leukoc Biol. 2010;87(5):779-89. http://dx.doi.org/10.1189/jlb.1109766

7. Sousa LF, Coelho FM, Rodrigues DH, Campos AC, Barcelos LS, Teixeira $\mathrm{MM}$ et al. Blockade of CXCR1/2 chemokine receptors protects against brain damage in ischemic stroke in mice. Clinics (São Paulo). 2013;68(3):391-4. http://dx.doi.org/10.6061/clinics/2013(03)OA17

8. Phipps MA. Assessment of neurologic deficits in stroke: acute-care and rehabilitation implications. Nurs Clin North Am. 1991;26(4):957-70.

9. Rostamian S, Mahinrad S, Stijnen T, Sabayan B, Craen AJ. Cognitive impairment and risk of stroke: a systematic review and meta-analysis of prospective cohort studies. Stroke. 2014;45(5):1342-8. http://dx.doi.org/10.1161/STROKEAHA.114.004658

10. Witko-Sarsat V, Rieu P, Descamps-Latscha B, Lesavre P, Halbwachs-Mecarelli L. Neutrophils: molecules, functions and pathophysiological aspects. Lab Invest. 2000;80(5):617-53.

11. Baker WB, Sun Z, Hiraki T, Putt ME, Durduran T, Reivich M et al. Neurovascular coupling varies with level of global cerebral ischemia in a rat model. J Cereb Blood Flow Metab. 2013;33(1):97-105. http://dx.doi.org/10.1038/jcbfm.2012.137

12. Ennaceur A, Delacour J. A new one-trial test for neurobiological studies of memory in rats. 1: behavioral data. Behav Brain Res. 1988;31(1):47-59. http://dx.doi.org/10.1016/0166-4328(88)90157-X

13. Antunes M, Biala G. The novel object recognition memory: neurobiology, test procedure, and its modifications. Cogn Process. 2012;13(2):93-110. http://dx.doi.org/10.1007/s10339-011-0430-z
14. Román GC, Tatemichi TK, Erkinjuntti T, Cummings JL, Masdeu JC, Garcia JH et al. Vascular dementia: diagnostic criteria for research studies: report of the NINDS-AIREN International Workshop. Neurology. 1993;43(2):250-60. http://dx.doi.org/10.1212/WNL.43.2.250

15. Shih AY, Blinder P, Tsai PS, Friedman B, Stanley G, Lyden PD et al. The smallest stroke: occlusion of one penetrating vessel leads to infarction and a cognitive deficit. Nat Neurosci. 2013;16(1):55-63. http://dx.doi.org/10.1038/nn.3278

16. Lynch MA. Long-term potentiation and memory. Physio Rev. 2004;84(1):87-136. http://dx.doi.org/10.1152/physrev.00014.2003

17. Zoppo GJ, Milner R, Mabuchi T, Hung S, Wang X, Berg Gl et al. Microglial activation and matrix protease generation during focal cerebral ischemia. Stroke. 2007;38(2 Suppl):646-51. http://dx.doi.org/10.1161/01.STR.0000254477.34231.cb

18. Lambertsen KL, Biber K, Finsen B. Inflammatory cytokines in experimental and human stroke.J Cereb Blood Flow Metab. 2012;32(9):1677-98. http://dx.doi.org/10.1038/jcbfm.2012.88

19. Avital A, Goshen I, Kamsler A, Segal M, Iverfeldt K, Richter-Levin G et al. Impaired interleukin-1 signaling is associated with deficits in hippocampal memory processes and neural plasticity. Hippocampus. 2003;13(7):826-34. http://dx.doi.org/10.1002/hipo.10135

20. Baune BT, Ponath G, Rothermundt M, Riess O, Funke $\mathrm{H}$, Berger K. Association between genetic variants of IL-1 beta, IL-6 and TNF-alpha cytokines and cognitive performance in the elderly general population of the MEMO-study. Psychoneuroendocrinology. 2008;33(1):68-76. http://dx.doi.org/10.1016/j.psyneuen.2007.10.002

21. McAfoose J, Baune BT. Evidence for a cytokine model of cognitive function. Neurosci Biobehav Rev. 2009;33(3):355-66. http://dx.doi.org/10.1016/j.neubiorev.2008.10.005

22. Yirmiya R, Goshen I. Immune modulation of learning, memory, neural plasticity and neurogenesis. Brain Behav Immun. 2011;25(2):181-213. http://dx.doi.org/10.1016/j.bbi.2010.10.015

23. Miranda AS, Lacerda-Queiroz N, Vilela MC, Rodrigues DH, Rachid MA et al. Anxiety-like behavior and proinflammatory cytokine levels in the brain of C57BL/6 mice infected with Plasmodium berghei (strain ANKA). Neurosci Lett. 2011;491(3):202-6. http://dx.doi.org/10.1016/j.neulet.2011.01.038

24. Calsavara AC, Rodrigues DH, Miranda AS, Costa PA, Lima CX, Vilela $M C$ et al. Late anxiety-like behavior and neuroinflammation in mice subjected to sublethal polymicrobial sepsis. Neurotox Res. 2013;24(2):103-8. http://dx.doi.org/10.1007/s12640-012-9364-1 